\title{
PENGARUH FAKTOR LOKASI TERHADAP KEPUTUSAN PEMBELIAN
}

\section{PRODUK}

Oleh: Siti Husnul Hotimah

Dosen STIA Pembangunan Jember

\begin{abstract}
Abstrak
Penelitian ini bertujuan untuk mengetahui apakah sub variabel pada variabel faktor lokasi (keterjangkauan, kelancaran arus lalu lintas, lingkungan, dan dekat dengan fasilitas umum) berpengaruh terhadap variabel keputusan pembelian pada CV. Wijaya Jember. Populasi dalam penelitian ini adalah semua konsumen CV. Wijaya yang melakukan transaksi pembelian di tempat tersebut. Sampel yang diambil sebanyak 80 responden dengan metode pengambilan sampel yang digunakan adalah Accidental sampling Method. Instrumen yang digunakan yaitu kuesioner yang pengukurannya menggunakan skala likert dengan 5 tingkatan.
\end{abstract} Kemudian dilakukan analisis data yang diperoleh dengan menggunakan analisis regresi linier berganda dengan pengujian hipotesis menggunakan uji F (uji mayor) dan uji t (uji minor). Dari analisis tersebut diperoleh persamaan regresi: " $\mathrm{Y}=4,311+0,413 \mathrm{X}_{1}+0,285 \mathrm{X}_{2}+0,471 \mathrm{X}_{3}+0,645 \mathrm{X}_{4}{ }^{6}$. Dimana melalui uji F (uji mayor) menunjukkan bahwa variabel faktor lokasi (X) secara simultan mempengaruhi variabel keputusan pembelian (Y). Kemudian melalui uji t menunjukkan bahwa sub variabel keterjangkauan $\left(X_{1}\right)$, kelancaran arus lalu lintas $\left(\mathbf{X}_{2}\right)$, lingkungan $\left(\mathbf{X}_{3}\right)$, dan dekat dengan fasilitas umum $\left(\mathrm{X}_{4}\right)$ secara individual mempengaruhi variabel keputusan pembelian (Y). Angka Adjusted R square sebesar 0,624 menunjukkan bahwa $62,4 \%$ variabel keputusan pembelian dapat dijelaskan melalui keempat sub variabel pada variabel faktor lokasi sedangkan sisanya 37,6\% dijelaskan oleh variabel lain diluar keempat sub variabel yang digunakan dalam penelitian ini. 


\section{PENDAHULUAN}

Pekembangan persaingan bisnis di Indonesia adalah salah satu fenomena yang sangat menarik untuk kita pelajari, terlebih dengan adanya globalisasi dalam bidang ekonomi yang semakin membuka peluang pengusaha asing untuk turut berkompetisi dalam menjaring konsumen lokal. Perusahaan lokal sebagai tuan rumah semakin dituntut untuk mengenali perilaku konsumen untuk kemudian menyesuaikan kemampuan perusahaan dengan kebutuhan mereka. Perilaku konsumen adalah suatu kegiatan individu yang secara langsung terlibat dalam mendapatkan dan mempergunakan barang atau jasa temasuk didalamnya proses pengambilan keputusan pada persiapan dan penentuan kegiatan tersebut. Perusahaan yang ingin survive harus mempunyai nilai lebih yang menjadikan perusahaan tersebut berbeda dengan perusahaan lain. Nilai lebih yang ditawarkan ini akan semakin memberikan kemantapan kepada calon konsumen untuk bertransaksi atau mendorong para konsumen lama untuk bertransaksi kembali.

Persentase kenaikan jumlah (berdirinya) percetakan terjadi luar biasa yaitu pada tahun 2011 sebesar 13\% dan pada tahun 2012 hanya sebesar 2,5\%. Bila ditilik dari wilayah berdirinya / perkembangannya terjadi di Kecamatan Sumbersari, Patrang, dan Kaliwates, yaitu kecamatan yang berada di dekat pusat kota Jember. Perusahaan percetakan ini dahulunya hanya melayani percetakan offset, namun dengan berjalannya waktu pemilik perusahaan berinovasi untuk menambah jenis jasa yang ditawarkann kepada konsumen yaitu jasa pengadaan barang (General Supplier). Sedangkan produk percetakan offset yang ditawarkan meliputi brosur, undangan, kalender, kartu nama, stiker, nota, sablon plastik, sampul raport, raport, kop amplop, kop surat, buku, bed lokasi, nama dada, dan lain - lain.

Dalam menumbuhkan minat beli dan akhirnya melakukan keputusan membeli tidaklah mudah. Banyak 
faktor yang dapat mempengaruhi hal itu. Baik dari faktor internal/dari dalam diri konsumen ataupun pengaruh eksternal yaitu rangsangan yang dilakukan oleh perusahaan. Perusahaan harus selalu mengamati perubahan perilaku konsumen sehingga dapat mengantisipasi perubahan perilaku tersebut, untuk kemudian dijadikan kajian dalam rangka memperbaiki strategi pemasarannya.

Strategi pemasaran adalah pernyataan pokok tentang dampak yang diharapkan akan dicapai dalam hal permintaan pada target pasar yang ditentukan. Dalam strategi pemasaran, ada tiga faktor utama yang menyebabkan terjadinya perubahan strategi dalam pemasaran yaitu: 1) Daur hidup produk. Strategi harus disesuaikan dengan tahap tahap daur hidup, yaitu tahap perkenalan, tahap pertumbuhan, tahap kedewasaan dan tahap kemunduran. 2) Posisi persaingan perusahaan di pasar. Strategi pemasaran harus disesuaikan dengan posisi perusahaan dalam persaingan, apakah memimpin, menantang, mengikuti atau hanya mengambil sebagian kecil dari pasar. 3) Situasi ekonomi. Strategi pemasaran harus disesuaikan dengan situasi ekonomi dan pandangan ke depan, apakah ekonomi berada dalam situasi makmur atau inflasi tinggi. Pada hakekatnya tujuan dari pemasaran adalah untuk mengetahui dan memahami sifat konsumen dengan baik sehingga produk yang ditawarkan dapat laku terjual.

Perusahaan jasa harus dapat merancang strategi pemasaran yang tepat dalam mencapai tujuan perusahaan, salah satunya adalah menentukan lokasi tempat untuk setiap bisnis merupakan suatu tugas penting bagi pemasar, karena keputusan yang salah dapat mengakibatkan kegagalan sebelum bisnis dimulai. Memilih lokasi berdagang merupakan keputusan penting untuk bisnis yang harus membujuk pelanggan untuk datang ke tempat bisnis dalam pemenuhan kebutuhannya. Pemilihan lokasi mempunyai fungsi yang strategis karena dapat ikut menentukan tercapainya tujuan badan usaha. Lokasi adalah berbagai kegiatan yang dilakukan perusahaan untuk 
membuat produknya mudah tujuan yaitu : (1) Ingin mengetahui diperoleh dan tersedia untuk pengaruh faktor lokasi terhadap konsumen sasaran. Penyedia jasa keputusan pembelian bagi konsumen, harus benar-benar mempertimbangkan, menyeleksi dan memilih lokasi yang responsif terhadap kemungkinan perubahan ekonomi, demografis, budaya, persaingan, dan peraturan di masa mendatang.

Rumusan masalah dalam penelitian ini adalah "Apakah Faktor Lokasi Berpengaruh Secara Simultan Maupun Parsial Terhadap Keputusan Pembelian Produk Percetakan?". (b) Ingin mengetahui pengaruh keterjangkauan terhadap keputusan pembelian bagi konsumen, (c) Ingin mengetahui pengaruh kelancaran arus lalu lintas terhadap keputusan pembelian bagi konsumen, (d) Ingin mengetahui pengaruh lingkungan terhadap keputusan pembelian bagi konsumen, (e) Ingin mengetahui pengaruh kedekatan perusahaan dengan fasilitas umum terhadap keputusan pembelian bagi konsumen.

Penelitian ini mempunyai beberap

\section{TINJAUAN PUSTAKA}

\section{Pemasaran}

Menurut Kotler (1997:8), "pemasaran adalah suatu proses sosial dan manajerial yang didalamnya individu dan kelompok mendapatkan apa yang mereka butuhkan dan inginkan dengan menciptakan, menawarkan dan mempertukarkan produk yang bernilai dengan pihak lain”. Sedangkan definisi menurut William J. Stanton (1984:7), "pemasaran adalah suatu sistem total dari kegiatan bisnis yang dirancang untuk merencanakan, menentukan harga, mempromosikan dan mendistribusikan barang-barang yang memuaskan keinginan dan jasa baik kepada para konsumen saat ini maupun konsumen potensial”. Pemasaran adalah sistem keseluruhan dari kegiatan-kegiatan usaha yang ditujukan untuk merencanakan, menentukan harga, mempromosikan, dan mendistribusikan barang dan jasa 
yang dapat memuaskan kebutuhan baik kepada pembeli yang ada maupun pembeli potensial (Swastha dan Handoko, 2004:4).

Manajemen

pemasaran

merupakan kegiatan yang

dikoordinasikan dan dikelola dengan baik. Definisi manajemen pemasaran menurut Kotler yang dikutip Swastha dan Handoko (1997:4) yaitu: "manajemen pemasaran adalah penganalisaan, perencanaan dan pengawasan program-program yang bertujuan menimbulkan pertukaran dengan pasar yang dituju dengan maksud untuk mencapai tujuan perusahaan”.

Bauran pemasaran menurut Kotler (2002:18), adalah sekumpulan alat pemasaran yang dapat digunakan oleh perusahaan untuk mencapai tujuan pemasarannya dalam pasar sasaran. Ada 4 unsur bauran pemasaran yang disingkat $4 \mathrm{P}$ (Product, Price, Promotion, dan Place). Penjelasan arti dari 4P sebagai berikut:

a. Product (produk)

Adalah segala sesuatu yang dapat ditawarkan ke pasar untuk diperhatikan, diperoleh dan digunakan atau dikonsumsi untuk dapat memenuhi kebutuhan dan keinginan meliputi barang fisik, jasa, orang, tempat, organisasi, gagasan dan ide.

b. Price (harga)

Yaitu jumlah uang yang harus dibayar oleh pelanggan untuk memperoleh produk atau jasa untuk memperoleh satu buah produk dan hendaknya harga akan dapat terjangkau oleh konsumen.

c. Place (tempat / lokasi)

Termasuk aktivitas perusahaan untuk menyalurkan produk atau jasa tersedia bagi konsumen. Serta merupakan keputusan distribusi menyangkut kemudahan akses terhadap jasa bagi para pelanggan. Tempat dimana produk tersedia dalam sejumlah saluran distribusi dan outlet yang memungkinkan konsumen dapat dengan mudah memperoleh suatu produk.

d. Promotion (promosi)

Berarti aktivitas yang meliputi berbagai metode, yaitu iklan, promosi penjualan, penjualan 
tatap muka dan hubungan masyarakat,

mengkomunikasikan produk dan membujuk pelanggan,

Menggambarkan berbagai macam cara yang ditempuh perusahaan dalam rangka menjual produk ke konsumen.

\section{Lokasi}

Tjiptono

(2008:185)

mendefinisikan secara garis besar, pendistribusian dapat diartikan sebagai kegiatan pemasaran yang berusaha memperlancar dan mempermudah penyampaian barang dan jasa dari produsen kepada konsumen, sehingga penggunaannya sesuai dengan yang diperlukan (jenis, jumlah, harga, tempat, dan saat dibutuhkan). Dengan kata lain proses distribusi merupakan aktivitas pemasaran yang mampu: (1) Menciptakan nilai tambah produk melalui fungsi-fungsi pemasaran yang dapat merealisasikan kegunaan bentuk, tempat, waktu dan kepemilikkan: (2) Memperlancar arus saluran pemasaran secara fisik dan non fisik. Yang dimaksd dengan arus pemasaran adalah aliran kegiatan yang terjadi diantara lembaga-lembaga pemasaran yang terlibat didalam proses pemasaran. Arus pemasaran meliputi barang fisi, arus kepemilikan, arus informasi, arus promosi, arus negoisasi, arus pembayaran, arus pendanaan, arus penanggung risiko dan arus pemesanan.

Pemilihan lokasi mempunyai fungsi yang strategis karena dapat ikut menentukan tercapainya tujuan badan usaha. Lokasi lebih tegas berarti tempat secara fisik (Sriyadi, 1991: 60). Lokasi adalah letak atau toko pengecer pada daerah yang strategis sehingga dapat memaksimumkan laba (Swastha dan Irawan, 2003: 339).

\section{a. Jenis-jenis Interaksi Lokasi}

Menurut Lupiyoadi (2001: 6162), "lokasi adalah tempat dimana perusahaan harus bermarkas melakukan operasi. Dalam hal ini ada 3 jenis interaksi yang mempengaruhi lokasi, yaitu:

1. Konsumen mendatangi pemberi jasa

Apabila keadaannya seperti ini maka lokasi menjadi sangat penting. Perusahaan sebaiknya 
memilih tempat dekat dengan konsumen sehingga mudah dijangkau, dengan kata lain harus strategis.

2. Pemberi jasa mendatangi konsumen

Dalam hal ini perusahaan melakukan kegiatan pemasaran yang berupa personal selling, yaitu dengan mendatangi konsumen yang sudah berlangganan sehingga terjalin komunikasi yang baik antara perusahaan dengan pembeli. Dengan adanya komunikasi yang baik diharapkan konsumen tersebut akan selalu menggunakan jasa perusahaan.

3. Pemberi jasa dan konsumen tidak bertemu secara langsung Berarti penyedia jasa dan konsumen berinteraksi melalui sarana tertentu seperti telepon, komputer, surat, ataupun media lainnya. Dalam hal ini penyedia jasa harus menjaga komunikasi antara kedua belah pihak sehingga terlaksana dengan baik dan konsumen merasa mudah dan nyaman dalam menggunakan jasa perusahaan.

\section{b. Faktor Pemilihan Lokasi}

Menurut Tjiptono (2004: 41-42), pemilihan lokasi memerlukan pertimbangan yang cermat terhadap beberapa faktor berikut:

1. Keterjangkauan, misalnya lokasi yang mudah dilalui atau mudah dijangkau sarana transportasi umum.

2. Kelancaran arus lalu lintas, ada dua hal yang diperhatikan:

- Banyaknya orang yang lalu lalang bisa memberikan peluang yang besar terjadinya impuls buying.

- Kepadatan dan kemacetan bisa menjadi hambatan.

3. Lingkungan sekitar yang nyaman yaitu daerah sekitar yang mendukung jasa yang ditawarkan.

4. Dekat dengan fasilitas umun, misalnya di dekat perusahaan tersedia beberapa fasilitas seperti toilet, mushola, toko, dan fasilitas lainnya.

Lokasi sering menentukan kesuksesan suatu jasa karena lokasi erat kaitannya dengan kadar potensial suatu perusahaan. Apabila lokasi percetakan menguntungkan, 
lokasinya strategis, memiliki kemudahan dalam transportasi, maka minat konsumen untuk menggunakan jasa percetakan dapat meningkat, sebab konsumen akan lebih mudah menjangkau percetakan tersebut.

\section{Tujuan Perusahaan dalam Pemasaran}

Perusahaan memiliki beberapa tujuan-tujuan diantaranya:

a. Meningkatkan penjualan dan laba

Dengan cara memperbesar atau memperbanyak omset penjualan, sehingga laba dapat meningkat dengan sendirinya.

b. Menguasai pasar

Memperbesar market share, untuk mencari dan menciptakan peluang baru untuk merebut market share pesaing.

c. Mengurangi saingan

Menciptakan/memproduksi

produk sejenis dengan mutu sama tetapi harga lebih rendah dari produk pesaing. Hal ini dapat mengurangi saingan dan antisipasii terhadap kemungkinan pesaing yang akan masuk ke dalam persaingan produk tersebut.

d. Menaikkan keunggulan produk tertentu di pasaran

Terutama untuk produk kelas tinggi, yaitu untuk meningkatkan keunggulan produk di depan pelanggannya dengan cara promosi, dan sebagainya.

e. Memenuhi permintaan pihakpihak tertentu

Tujuan perusahaan juga terdapat 2 kategori, yaitu :

1. Permintaan.

Permintaan adalah keinginan yang didukung oleh kemampuan yang dimiliki oleh seseorang konsumen untuk membeli.

2. Penawaran.

Penawaran adalah jumlah barang atau jasa yang ditawarkan produsen pada berbagai tingkat harga pada suatu waktu tertentu.

\section{Keputusan Pembelian}

Minat beli yang ada dalam diri konsumen merupakan fenomena yang sangat penting dalam kegiatan pemasaran, minat beli merupakan suatu perilaku konsumen yang melandaskan suatu 
keputusan pembelian yang hendak dilakukan (Swastha dan Irawan 2001: 339). Pengertian keputusan pembelian, menurut Kotler \& Armstrong (2001: 226) adalah tahap dalam proses pengambilan keputusan pembeli di mana konsumen benarbenar membeli. Pengambilan keputusan merupakan suatu kegiatan individu yang secara langsung terlibat dalam mendapatkan dan mempergunakan produk yang ditawarkan. Keputusan yang dipilih konsumen dalam memilih perusahaan adalah kunci bagi kelangsungan siklus sebuah perusahaan karena konsumen merupakan aset.

Assauri (2004: 141), menyatakan keputusan pembelian merupakan suatu proses pengambilan keputusan akan pembelian yang mencakup penentuan apa yang akan dibeli atau tidak melakukan pembelian dan keputusan itu diperoleh dari kegiatan-kegiatan sebelumnya. Nickels et al, (2009: 106), "proses pengambilan keputusan konsumen adalah ada banyak pengaruh pada konsumen ketika mereka memutuskan barang dan jasa yang akan dibeli". Pemasar memiliki sedikit pengaruh tetapi biasanya tidak sekuat pengaruh sosiokultural membantu konsumen dalam pencarian informasi mereka dan evaluasi alternatif mereka merupakan fungsi utama pemasar.

\section{a. Peran Konsumen dalam}

\section{Keputusan Pembelian}

Pemasar harus dapat mengetahui siapa yang membuat keputusan pembelian dan apa saja peran yang dilakukan konsumen tersebut. Mengenali konsumen untuk beberapa produk tertentu cukup mudah, tetapi pemasar juga perlu mengidentifikasi peran konsumen dalam keputusan pembelian. Kotler (2005: 220) membedakan lima peran yang dimainkan orang dalam keputusan pembelian, yaitu:

1. Pencetus yaitu seseorang yang pertama kali mengusulkan gagasan untuk membeli produk atau jasa.

2. Pemberi pengaruh yaitu seseorang yang pandangan atau sarannya mempengaruhi keputusan. 
3. Pengambil keputusan yaitu pemasaran yang tepat dengan para seseorang yang mengambil keputusan untuk setiap komponen keputusan pembelian: apakah membeli, tidak membeli, bagaimana membeli dan dimana akan membeli.

4. Pembeli yaitu orang yang melakukan pembelian sesungguhnya.

5. Pemakai yaitu seseorang yang mengkonsumsi atau menggunakan produk / jasa yang bersangkutan.

Dengan mengetahui pelaku utama dan peranan yang mereka mainkan akan membantu para pemasar menyelaraskan program

\section{Gambar 1.}

\section{b. Tahap - tahap Pengambilan}

\section{Keputusan Pembelian}

Pada umumnya manusia

bertindak rasional dan mempertimbangkan segala jenis informasi yang tersedia dan mempertimbangkan segala sesuatu yang bisa muncul dari tindakannya sebelum melakukan sebuah perilaku tertentu. Para konsumen akan melewati lima tahapan dalam melakukan pembelian yaitu: pengenalan masalah, pencarian informasi, evaluasi alternatif, keputusan pembelian, dan perilaku pasca pembelian (Kotler, 2005: 36).

Tahap - Tahap Pengambilan Keputusan Pembelian

\begin{tabular}{|c|}
$\begin{array}{c}\text { Pengenalan } \\
\text { Masalah }\end{array} \rightarrow \begin{array}{l}\text { Pencarian } \\
\text { Informasi }\end{array} \rightarrow \begin{array}{c}\text { Evaluasi } \\
\text { Alternatif }\end{array} \rightarrow \begin{array}{l}\text { Keputusan } \\
\text { Pembelian }\end{array} \rightarrow \begin{array}{c}\text { Perilaku } \\
\text { Pasca } \\
\text { Pembelian }\end{array}$ \\
\hline
\end{tabular}

Sumber : Kotler (2005:36) Manajemen Pemasaran

Penjelasan lebih lanjut
mengenai tahapan diatas
adalah sebagai berikut:

\section{Pengenalan Masalah}

Proses pembelian dimulai ketika pembeli mengenali masalah atau kebutuhan. Kebutuhan tersebut dapat dicetuskan oleh rangsangan internal atau eksternal. Rangsangan ini akan berubah menjadi dorongan. Berdasarkan dorongan yang ada pada diri konsumen maka konsumen akan mencari obyek 
yang diketahui untuk dapat memuaskan dorongan tersebut.

\section{Pencarian Informasi}

Seorang konsumen yang minatnya telah tergugah hanya akan ada dua kemungkinan yaitu, mencari informasi secara aktif atau mencari informasi kemudian hanya mengendapkannya dalam ingatan. Sumber informasi konsumen dapat dikelompokkan ke dalam lima kategori berikut:

a. Sumber Internal, berupa pengalaman sebelumnya dalam menangani kebutuhan serupa.

b. Sumber Kelompok, yaitu pihak-pihak relevan lain (seperti teman, keluarga, tetangga, dan rekan kerja) yang diyakini konsumen memiliki keahlian khusus dalam keputusan pembelian terkait.

c. Sumber Pemasaran, berupa iklan, wiraniaga, dealer, kemasan, dan pajangan.

d. Sumber Publik, meliputi publisitas (seperti artikel koran tentang produk) dan pemeringkatan independen terhadap produk. (contohnya, laporan hasil riset produk dan warta konsumen).

e. Sumber Eksperiensial, yaitu menangani, menilai, dan mungkin pula mencoba produk atau jasa sewaktu berbelanja.

\section{Evaluasi Alternatif}

Tidak ada proses evaluasi tunggal sederhana yang digunakan oleh semua konsumen atau oleh salah satu konsumen dalam semua situasi pembelian, itu berarti setiap konsumen pasti memiliki beberapa alternatif sebelum akhirnya menjatuhkan pilihan. Beberapa konsep dasar dari proses evaluasi konsumen:

a. Konsumen berusaha memenuhi kebutuhan

b. Konsumen mencari manfaat tertentu dari solusi produk

c. Konsumen memandang masing-masing produk sebagai sekumpulan atribut dengan kemampuan yang berbeda-beda dalam memberikan manfaat yang 
digunakan untuk memuaskan kebutuhan itu.

\section{Keputusan Pembelian}

Dalam tahap evaluasi para konsumen membentuk preferensi atas merek-merek yang ada di dalam kumpulan pilihan. Konsumen tersebut juga dapat membentuk niat untuk membeli merek yang paling disukai. Namun ada dua faktor yang dapat berada di antara niat pembelian dan keputusan pembelian, pertama adalah sikap orang lain. Sejauh mana sikap orang lain mengurangi alternatif yang disukai seseorang akan bergantung pada dua hal yaitu:

a. Intensitas sikap negatif orang lain terhadap alternatif yang disukai konsumen dan motivasi konsumen untuk menuruti keinginan orang lain.

b. Faktor situasi yang tidak terantisipasi yang dapat muncul dan mengubah niat pembelian. Faktor-faktor tersebut diantaranya seperti faktor pendapatan, keluarga, harga, dan keuntungan dari produk tersebut.

Dalam melaksanakan niat pembelian, konsumen dapat membuat sub keputusan pembelian: keputusan merek, keputusan pemasok, keputusan kuantitas, keputusan waktu, dan keputusan metode pembayaran.

\section{Perilaku Pasca Pembelian}

Setelah membeli produk maka konsumen akan mengalami tingkat kepuasan atau ketidakpuasan. Jika produk dan perusahaan memperlakukan konsumen sesuai dengan harapan maka konsumen puas, jika melebihi harapan konsumen akan sangat puas, jika produk dan perusahaan memperlakukan konsumen kurang dari harapan maka konsumen akan tidak puas. Kepuasan konsumen akan membawa implikasi pada perilaku pembeliaan (repurchase) atau bahkan merekomendasikan (recommended) produk tersebut kepada orang lain untuk membelinya. 


\section{Hubungan Faktor Lokasi dengan}

\section{Keputusan Pembelian}

Lokasi adalah faktor yang sangat penting dalam bauran pemasaran, pemilihan lokasi yang tepat dan strategis pada sebuah gerai atau toko akan lebih sukses dibandingkan gerai lainnya yang berlokasi kurang strategis (Berman \& Evans dalam Ma'ruf 2006: 113). Pemilihan lokasi untuk berbisnis harus dilakukan secara hati - hati. Meskipun kesuksesan tidak hanya bergantung pada lokasi bisnis, tetapi faktor lokasi akan mempengaruhi kesuksesan sebuah bisnis. Lamb, et al (2001: 102) berpendapat bahwa "faktor keselamatan dan keamanan dari lokasi merupakan salah satu variabel yang memberi kontribusi pada pertimbangan konsumen dalam menggunakan jasa yang ditawarkan”.
Meurut Tjiptono (2004: 41-42), pemilihan lokasi memerlukan pertimbangan yang cermat terhadap beberapa faktor, yaitu

Keterjangkauan, (2) Kelancaran arus lalu lintas, (3) Lingkungan sekitar yang nyaman, (4) Dekat dengan fasilitas umum.

Kotler (2005: 220) membedakan lima peran yang dimainkan orang dalam keputusan pembelian, yaitu: (1) Pencetus, (2) Pemberi pengaruh, (3) Pengambil keputusan, Pembeli, (5) Pemakai.Dari kelima peran tersebut yang akan dijadikan indikator dari keputusan pembelian (variabel Y) yaitu: pemberi pengaruh, pengambil keputusan, dan pemakai.

Berdasarkan uraian diatas maka dapat disusun sebuah kerangka pemikiran teoritis seperti yang tersaji pada gambar sebagai berikut:

Gambar 2.

\section{Kerangka Pemikiran Teoritis}

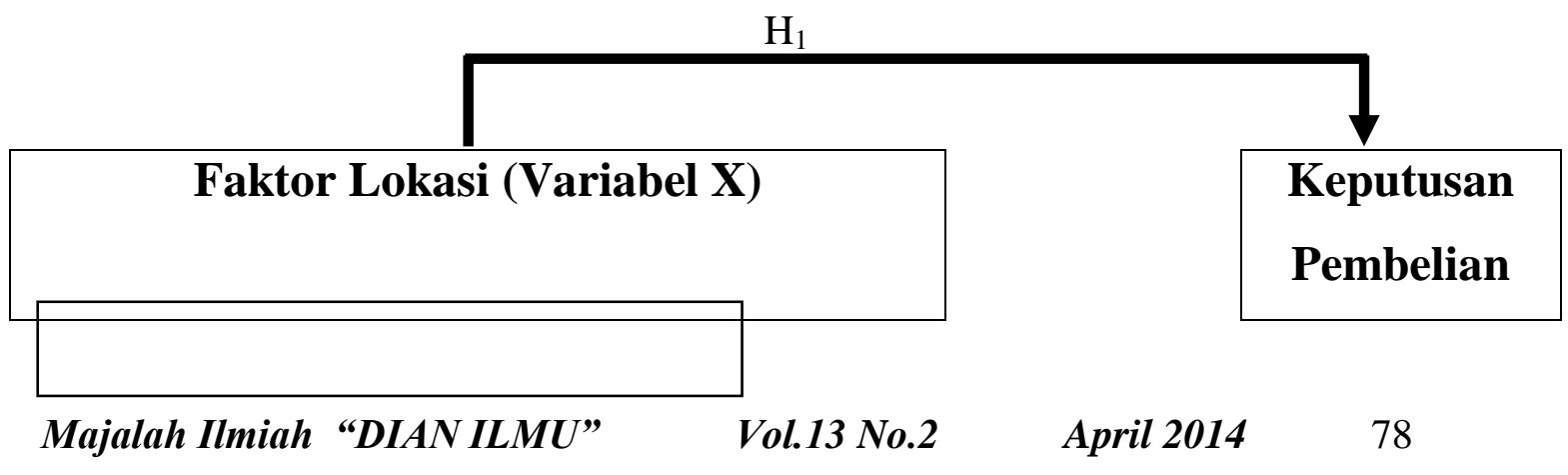




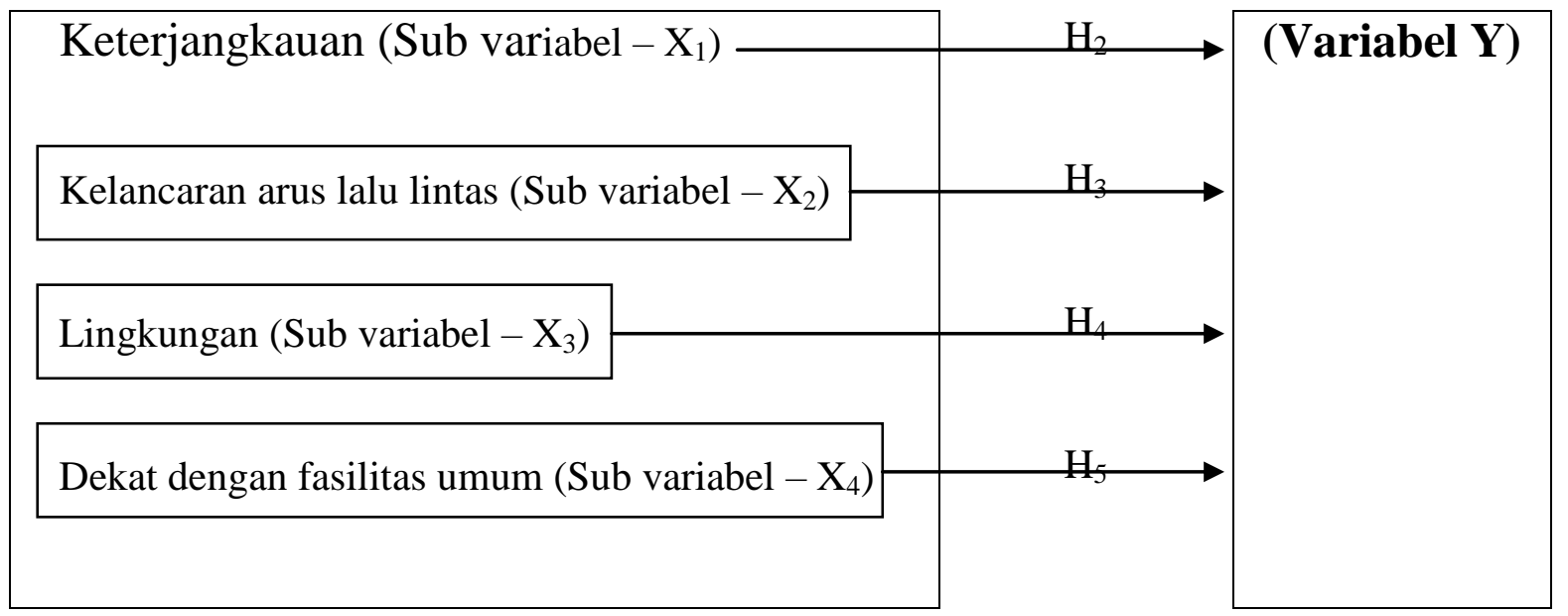

Keterangan: $\longrightarrow$ Hipotesis mayor

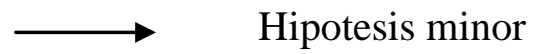

Sumber: Data yang diolah untuk penelitian ini, 2014.

\subsection{Hipotesis}

Menurut Sugiyono (2008: 221), "hipotesis merupakan suatu ide untuk mencari fakta yang harus dikumpulkan". Hipotesis adalah suatu pernyataan sementara atau dugaan yang paling memungkinkan yang masih harus dicari kebenarannya. Hubungan antar variabel dalam penelitian ini memiliki hipotesis sebagai berikut:

a. Hipotesis mayor:

$$
\begin{array}{rlr}
\mathrm{H}_{1} & \text { : Variabel faktor lokasi } \\
& \text { memiliki pengaruh yang } \\
& \text { positif dan } & \text { signifikan } \\
\text { terhadap } & & \text { variabel } \\
& \text { keputusan pembelian. }
\end{array}
$$

b. Hipotesis minor:
$\mathrm{H}_{2}$ : Sub variabel keterjangkauan memiliki pengaruh yang positif dan signifikan terhadap variabel keputusan pembelian.

$\mathrm{H}_{3}$ : Sub variabel kelancaran arus lalu lintas memiliki pengaruh yang positif dan signifikan terhadap variabel keputusan pembelian.

$\mathrm{H}_{4}$ : Sub variabel lingkungan memiliki pengaruh yang positif dan signifikan terhadap variabel keputusan pembelian.

$\mathrm{H}_{5}$ : Sub variabel dekat dengan fasilitas umum memiliki pengaruh yang positif dan 


$\begin{array}{lrl}\text { signifikan } & \text { terhadap } & \text { pembelian. } \\ \text { variabel } & \text { keputusan }\end{array}$

\section{METODE PENELITIAN}

Penelitian ini dilakukan di CV. Wijaya Jember tepatnya di Jl. KH. Wahid Hasyim No.45 Jember selama kurun waktu 3 bulan yaitu sejak bulan April 2013 sampai dengan Juni 2013. Variabel dalam penelitian ini meliputi (1) keputusan pembelian (variabel Y), keterjangkauan $\left(\mathrm{X}_{1}\right)$, (3) kelancaran arus lalu lintas $\left(\mathrm{X}_{2}\right)$, (4) lingkungan $\left(\mathrm{X}_{3}\right)$, dan dekat dengan fasilitas umum $\left(\mathrm{X}_{4}\right)$. Populasi dalam penelitian ini adalah semua konsumen yang menggunakan jasa CV. Wijaya Jember. Jumlah konsumen yang tercatat pada data konsumen CV. Wijaya yaitu sebanyak 370 orang. Metode pengambilan sampel yang digunakan adalah Accidental Sampling Method dengan jumlah sampel sebanyak 80 responden.

Metode pengumpulan data yang dipergunakan dalam penelitian ini adalah: (1) Studi Pustaka, dan (2) Kuesioner. Setelah data terkumpul dan diolah selanjutnya data dianalisis dengan tahapan : (1) Uji Validitas, (2) Uji Reliabilitas, (3) Uji Asumsi Klasik, (4) Analisis Regresi Linier Berganda, dan (5) Uji Hipotesis. Uji Hipotesis yang digunakan meliputi Uji F dan Uji t.

\section{HASIL PENELITIAN}

\section{Uji Validitas}

Uji validitas akan menguji masing-masing variabel yang digunakan dalam penelitian ini, dimana keseluruhan variabel penelitian memuat 13 pernyataan yang harus dijawab oleh responden. Adapun kriteria yang digunakan dalam menentukan valid tidaknya pernyataan yang digunakan dalam penelitian ini adalah sebagai berikut: tingkat kepercayaan $=95 \%(\propto=$ 
$5 \%$ ), derajat kebebasan $(\mathrm{df})=\mathrm{n}-2=$ $80-2=78$, didapat $r_{\text {tabel }}=0,2199$. Jika $\mathrm{r}$ hitung (untuk tiap butir dapat dilihat pada kolom Corrected Item Total Correlation) lebih besar dari $\mathrm{r}$ tabel dan nilai $\mathrm{r}$ positif, maka butir pernyataan dikatakan valid. Berdasarkan analisis yang telah dilakukan, maka hasil pengujian menunjukan bahwa nilai dari $\mathrm{r}$ hitung keseluruhan variabel dan sub variabel yang diuji bernilai positif dan lebih besar dari nilai $r_{\text {tabel. }}$ Maka dapat diambil kesimpulan, bahwa seluruh butir indikator yang digunakan dalam penelitian ini lolos dalam uji validitas dan dinyatakan valid.

\section{Uji Reliabilitas}

Uji reliabilitas digunakan untuk mengukur konsistensi konstruk atau variabel penelitian. Untuk mengukur uji reliabilitas dilakukan dengan menggunakan uji statistik Cronbach Alpha $(\propto)$. Suatu konstruk atau variabel dikatakan reliabel jika memberikan nilai koefisien Alpha lebih besar dari 0,60. Hasil uji reliabilitas dalam penelitian ini menunjukkan bahwa nilai koefisien Alpha dari variabel dan sub variabel yang diteliti menunjukkan hasil yang beragam. Akan tetapi, semua item pernyataan tersebut memiliki nilai koefisien Alpha lebih besar dari 0,60. Dengan demikian dapat disimpulkan bahwa alat ukur yang digunakan dalam penelitian ini adalah reliabel.

\section{Uji Asumsi Klasik}

\section{a. Uji Normalitas}

Uji normalitas bertujuan untuk menguji apakah dalam model regresi variabel dependen dan sub variabel dari variabel independen keduanya mempunyai distribusi normal atau tidak. Deteksi normalitas dengan melihat penyebaran titik-titik pada sumbu diagonal grafik. Analisis grafik dilakukan dengan melihat histogram dan normal probability plot. Hasil pengujian normalitas dengan analisis grafik melalui SPSS versi 16.0 dapat dilihat pada gambar 2 dan gambar 3 sebagai berikut:

\section{Gambar 3.}

Histogram 


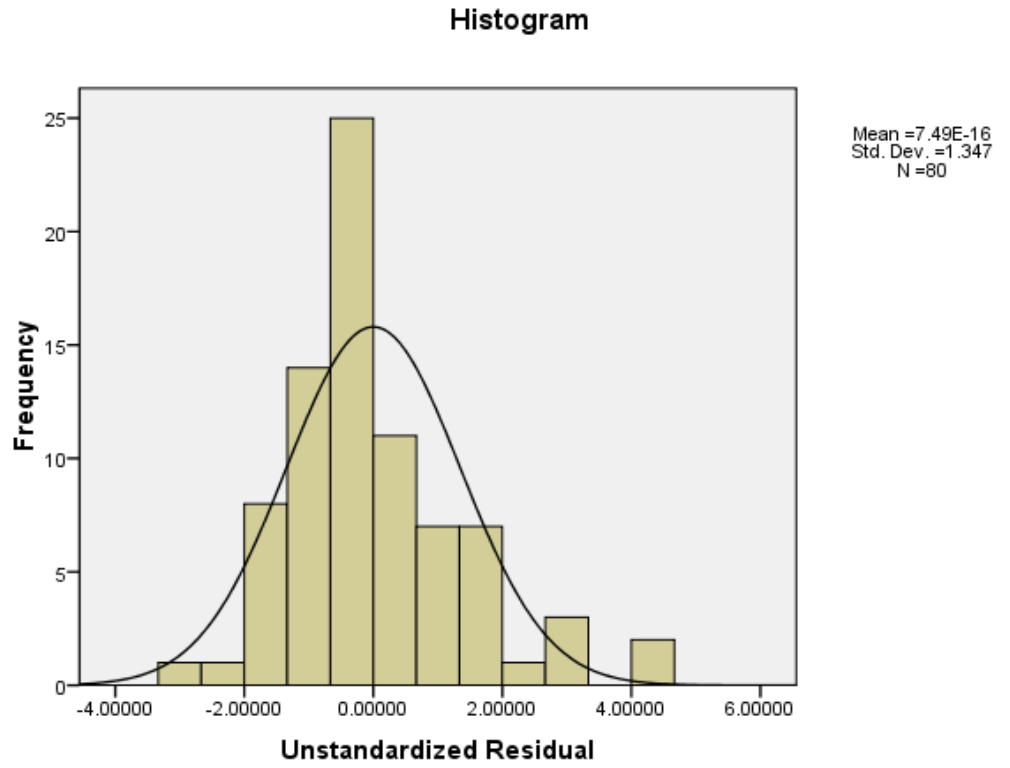

Sumber: Data primer yang diolah dengan SPSS 16.0, 2014

Dengan melihat tampilan grafik dan berbentuk simetris, tidak histogram di atas dapat disimpulkan menceng (skewness) ke kanan atau bahwa grafik histogram ke kiri.

menunjukkan pola distribusi normal 
Gambar 4.

\section{Grafik normal probability plot}

\section{Normal P-P Plot of Unstandardized Residual}

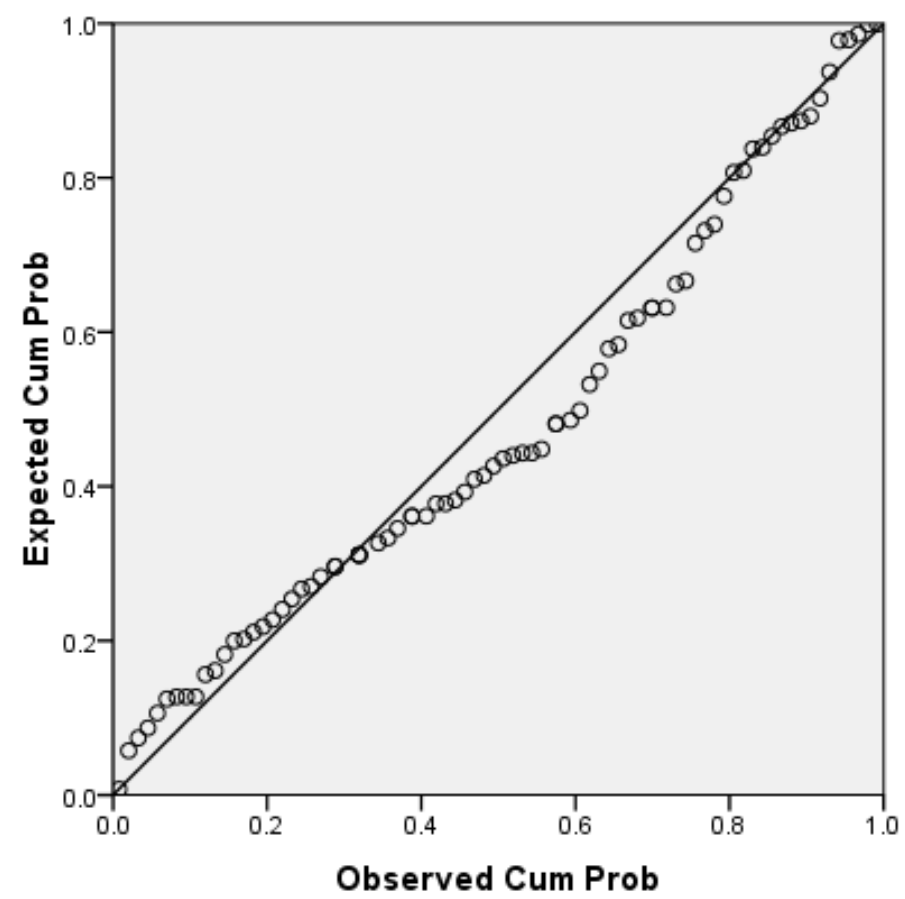

Sumber: Data primer yang diolah dengan SPSS 16.0, 2014

Berdasarkan grafik normal regresi ditemukan adanya korelasi probability plot diatas maka dapat antar sub variabel dari variabel bebas diketahui bahwa data menyebar (independen). Model regresi yang disekitar garis diagonal dan baik seharusnya tidak terjadi korelasi mengikuti arah garis diagonal. Dari di antara sub variabel dari variabel kedua grafik tersebut maka dapat bebas. Jika nilai Variance Inflation dinyatakan bahwa model regresi Factor (VIF) kurang dari 10 dan nilai pada penelitian ini memenuhi asumsi tolerance di atas 0,10. Maka model normalitas.

\section{b. Uji Multikolinearitas}

regresi terbebas dari gejala multikolinearitas. Hasil uji

Uji multikoliniaritas bertujuan untuk menguji apakah dalam model multikolinearitas menunjukan bahwa tidak ada sub variabel yang memiliki 
nilai VIF lebih besar dari 10 dan nilai tolerance yang lebih kecil dari 10\% yang berarti bahwa tidak terdapat korelasi antar sub variabel yang lebih besar dari $95 \%$, maka dapat disimpulkan bahwa tidak ada multikolinearitas antar sub variabel dari variabel independen dalam model regresi. Atau dengan kata lain model regresi dalam penelitian ini terbebas dari gejala multikolinearitas.

\section{c. Uji Heteroskedastisitas}

Tujuan pengujian ini adalah untuk mengetahui apakah dalam model regresi terjadi ketidaksamaan variance dari residual satu pengamatan ke pengamatan yang lain. Jika variance dari residual satu pengamatan ke pengamatan yang lain tetap maka disebut homokedastisitas, namun jika berbeda disebut dengan heteroskedastisitas. Model regresi yang baik adalah homokedastisitas atau tidak terjadi heteroskedastisitas. Hasil uji heteroskedastisitas dapat dilihat melalui scatterplot pada gambar 5 dibawah ini:

\section{Gambar 6.}

\section{Hasil Uji Heteroskedastisitas (Scatterplot)}

\section{Dependent Variable: Keputusan Pembelian}

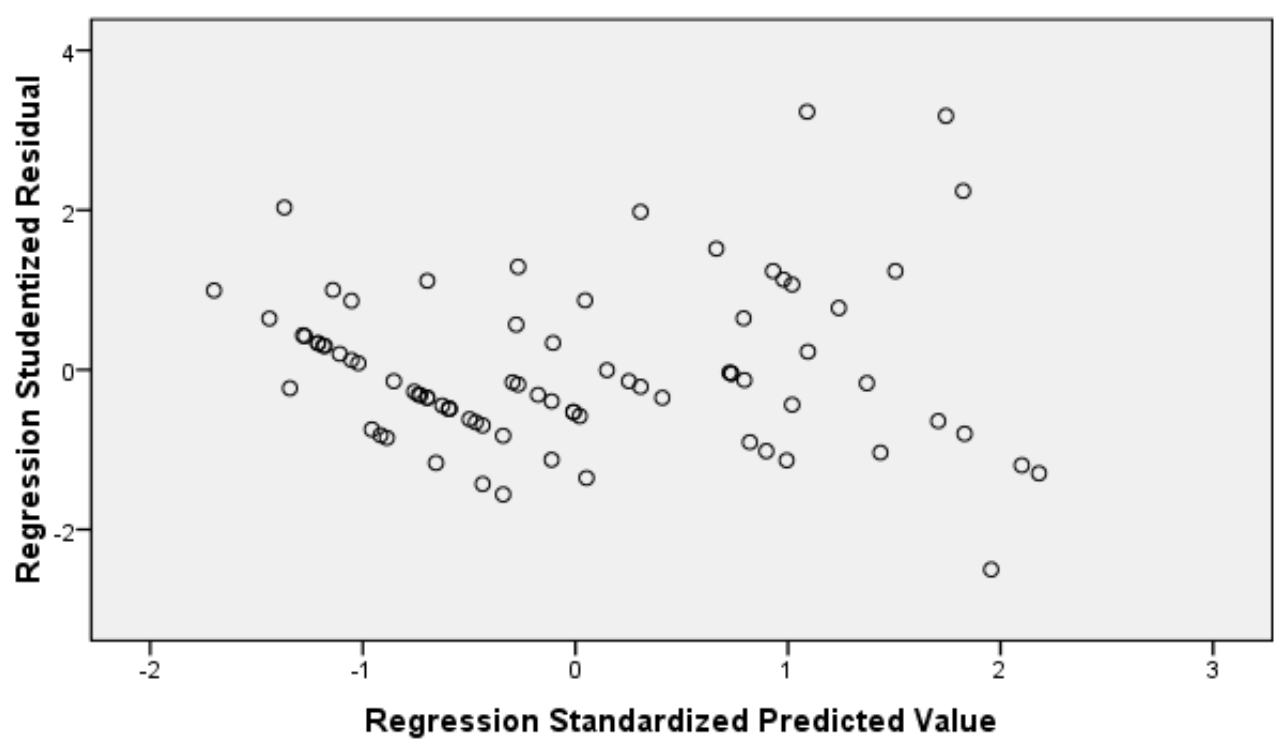

Sumber: Data primer yang diolah dengan SPSS 16.0, 2014 
Dari gambar scatterplot di atas dapat terlihat bahwa titik-titik menyebar secara acak baik diatas maupun di bawah nol pada sumbu Y dan tidak membentuk suatu pola tertentu. Dengan demikian dapat disimpulkan bahwa tidak terjadi heteroskedastisitas pada model regresi, oleh karena itu model regresi dalam penelitian ini layak dipakai untuk memprediksi keputusan pembelian berdasarkan masukan sub variabel dari variabel independen yang meliputi keterjangkauan, kelancaran arus lalu lintas, lingkungan, dan dekat dengan fasilitas umum.

\section{Analisis Regresi Linier Berganda}

Besarnya perubahan pada variabel dependen akibat perubahan pada sub variabel dari variabel independen secara parsial dapat dijelaskan melalui persamaan regresi yang diperoleh.

Berdasarkan pada hasil analisis yang telah dilakukan, maka persamaan regresi yang terbentuk adalah sebagai berikut: "Y $=4,311+$ diketahui bahwa besarnya nilai koefisien determinasi ditunjukkan oleh nilai Adjusted $R$ Square yaitu sebesar 0,624 yang artinya bahwa variasi dari semua sub variabel dari variabel bebas yaitu keterjangkauan, kelancaran arus lalu lintas, lingkungan dan dekat dengan fasilitas umum dapat menerangkan variabel keputusan pembelian sebesar $62,4 \%$, sedangkan sisanya sebesar $37,6 \%$ diterangkan oleh variabel lain yang tidak diajukan dalam penelitian ini.

\section{Pengujian Hipotesis}

\section{a. Uji F (Uji Mayor)}

Uji F (uji mayor) digunakan untuk menguji ada tidaknya pengaruh variabel faktor lokasi (variabel $\mathrm{X}$ ) terhadap variabel keputusan pembelian (variabel Y) secara simultan (bersama-sama). Hasil uji F (uji mayor) menunjukkan hasil perhitungan uji F ( uji mayor) diperoleh nilai $F_{\text {hitung }}$ sebesar 33,798 dengan tingkat signifikansi sebesar $0,000(<0,05)$. Sementara nilai $F_{\text {tabel }}$ 
sebesar 2,49 (dari perhitungan df1 = $\mathrm{k}-1=5-1=4$ dan df $2=\mathrm{n}-\mathrm{k}=$ $80-5=75$ diperoleh $F$ tabel sebesar 2,49). Ini berarti bahwa $F$ hitung $(33,798)>F$ tabel $(2,49)$ dengan demikian maka $\mathrm{H}_{0}$ ditolak dan $\mathrm{H}_{\mathrm{a}}$ diterima, artinya bahwa variabel faktor lokasi yang terdiri dari sub variabel keterjangkuan, kelancaran arus lalu lintas, lingkungan, dan dekat dengan fasilitas umum berpengaruh secara simultan atau bersama-sama terhadap variabel keputusan pembelian pada $\mathrm{CV}$. Wijaya Jember.

\section{b. Uji t (Uji Minor)}

Uji t (uji mnor) digunakan untuk mengetahui signifikansi pengaruh sub variabel keterjangkauan, kelancaran arus lalu lintas, lingkungan, dan dekat dengan fasilitas umum secara parsial atau individual menerangkan variabel keputusan pembelian. Hasil uji t (uji minor) menunjukan bahwa:

1. Dari tabel 4.11 dapat kita lihat bahwa nilai $\mathrm{t}$ hitung pada sub variabel keterjangkauan adalah sebesar 2,059 dengan tingkat signifikansi sebesar 0,043 . Karena nilai $t_{\text {hitung }}$ lebih besar dari $\mathrm{t}$ tabel yaitu $(2,059)>$ $(1,99210) \quad$ dan nilai signifikansinya $0,043<0,05$ maka $\mathrm{H}_{0}$ ditolak dan $\mathrm{H}_{\mathrm{a}}$ diterima.

2. Dari tabel 4.11 dapat kita lihat bahwa nilai $\mathrm{t}$ hitung pada sub variabel kelancaran arus lalu lintas adalah sebesar 2,000 dengan tingkat signifikansi sebesar 0,049. Karena nilai t hitung lebih besar dari $\mathrm{t}$ tabel yaitu $(2,000)>(1,99210)$ dan nilai signifikansinya $0,049<0,05$ maka $\mathrm{H}_{0}$ ditolak dan $\mathrm{H}_{\mathrm{a}}$ diterima.

3. Dari tabel 4.11 dapat kita lihat bahwa nilai $\mathrm{t}$ hitung pada sub variabel lingkungan adalah sebesar 2,872 dengan tingkat signifikansi sebesar 0,005. Karena nilai $\mathrm{t}$ hitung lebih besar dari $\mathrm{t}$ tabel yaitu $(2,872)>$ $(1,99210)$ dan nilai signifikansinya $0,005<0,05$ maka $\mathrm{H}_{0}$ ditolak dan $\mathrm{H}_{\mathrm{a}}$ diterima.

4. Dari tabel 4.11 dapat kita lihat bahwa nilai $\mathrm{t}$ hitung pada sub variabel dekat dengan fasilitas umum adalah sebesar 3,722 
dengan tingkat signifikansi sebesar 0,000. Karena nilai $t_{\text {hitung }}$ lebih besar dari $\mathrm{t}$ tabel yaitu $(3,722)>(1,99210)$ dan nilai signifikansinya $0,000<0,05$

maka $\mathrm{H}_{0}$ ditolak dan $\mathrm{H}_{\mathrm{a}}$ diterima.

\section{KESIMPULAN}

Berdasarkan hasil analisis data yang telah dilakukan terhadap seluruh data yang diperoleh, maka dapat diambil kesimpulan sebagai berikut:

1. Persamaan regresi yang diperoleh dalam penelitian ini yaitu:

"Y $\mathrm{Y}=4,311+0,413 \mathrm{X}_{1}+0,285 \mathrm{X}_{2}$

$+0,471 \mathrm{X}_{3}+0,645 \mathrm{X}_{4} "$

2. Variabel faktor lokasi lalu lintas, lingkungan, dan dekat dengan fasilitas umum) memiliki pengaruh yang positif dan signifikan terhadap variabel keputusan keputusan pembelian.

3. Sub variabel keterjangkauan memiliki pengaruh yang positif dan signifikan terhadap variabel keputusan pembelian.

4. Sub variabel kelancaran arus lalu lintas memiliki pengaruh yang positif dan signifikan terhadap variabel keputusan pembelian.
5. Sub variabel lingkungan memiliki pengaruh yang positif dan signifikan terhadap variabel keputusan pembelian.

6. Sub variabel dekat dengan fasilitas umum memiliki pengaruh yang positif dan signifikan terhadap variabel keputusan pembelian.

7. Koefisien determinasi $\left(\mathrm{R}^{2}\right)$ sebesar 0,624 menunjukkan bahwa sub variabel pada variabel faktor lokasi (keterjangkauan, kelancaran arus lalu lintas, lingkungan, dan dekat dengan fasilitas umum) memberikan kontribusi terhadap variabel keputusan pembelian sebesar 62,4\%, sedangkan sisanya $37,6 \%$ dipengaruhi oleh variabel lain yang tidak diteliti dalam penelitian ini. 


\section{DAFTAR PUSTAKA}

\begin{tabular}{lrr} 
& Buku & Pedoman \\
\hline Penulisan & Skripsi & STIA \\
Pembangunan Jember. & Tahun \\
2008. & \\
\multicolumn{2}{l}{ Kabupaten Jata dan } & Statistik \\
2010, 2011, dan 2012. & Tahun
\end{tabular}

Algrina Agnes Ulus. 2013. Bauran Pemasaran Pengaruhnya terhadap Keputusan Pembelian Mobil Daihatsu pada PT. Astra Internasional Manado. Jurnal EMBA Volume 1 No.4 Hal. 1136. Universitas Sam Ratulangi. Manado.

Arikunto, Suharsimi. 2005. Manajemen Penelitian. Jakarta. Rineka Cipta. 2006. Prosedur

Penelitian suatu Pendekatan Praktik. Edisi Revisi VI. Jakarta. PT. Rineka Cipta.

Assauri, Sofjan. 2004. Manajemen Pemasaran. Jakarta. Radja Grafindo.

Budiarto, E. 2001. Biostatistika untuk Kedokteran dan Kesehatan Masyarakat. Jakarta. Agung Ceto.

Bungin, Burhan. 2005. Metodologi Penelitian Kuantitatif. Jakarta. Kencana Prenada Media Group.

Creswell, Jhon W. 1994. Researc Design: Qualitative and Quantitative Approach. California. Sage Publication.

Ghozali, Imam. 2007. Aplikasi Analisis Multivariate dengan Program SPSS. Semarang. Universitas Diponegoro.

2005. Aplikasi Analisis Multivariate dengan
Program SPSS. Semarang. Universitas Diponegoro.

Hendra Fure. 2013. Lokasi, Keberagaman Produk, Harga, dan Kualitas Pelayanan Pengaruhnya terhadap Minat Beli pada Pasar Tradisional Bersehati Calaca. Jurnal EMBA Volume 1 No.3 Hal. 274-276. Universitas Sam Ratulangi. Manado.

Kotler, Philip. 1997. Manajemen Pemasaran. Jakarta.

Prenhallindo.

2002. Manajemen Pemasaran, Analisa Perencanaan, Implementasi dan Control. Edisi Kesembilan. Jilid 1 dan Jilid 2. Jakarta. Prenhallindo.

Kotler, Philip. 2005. Manajemen Pemasaran. Jilid I dan II. Indeks. Jakarta. Salemba Empat.

\& Armstrong, Gary. 2001. Prinsip-Prinsip Pemasaran. Jakarta. Erlangga.

Kristanto, Harianto. 2004. Konsep dan Perancangan Database. Yogyakarta. Andy Offset.

Lamb, Charles W. et al. 2001. Pemasaran. Buku I Edisi Pertama. Jakarta. Salemba Empat.

Lupiyoadi, Rambat. 2001. "Manajemen Pemasaran Jasa Teori dan Praktik". Jakarta. Salemba Empat.

Ma'ruf. 2006. Pemasaran Ritel. Jakarta. PT. Gramedia Pustaka Utama.

Nickels William G., James M. McHugh, Susan M. McHugh. 
2009: 106. Pengantar Bisnis (Understanding Business). edisi 8. buku 2. Jakarta. Salemba Empat.

Sriyadi. 1991. Bisnis Pengantar Ilmu Perusahaan Modern. Semarang. IKIP Press.

Santoso, Singgih. 2002. Statistik

Multivariat. Jakarta. PT. Elex

Media Komoutindo.

Stanton, J. William. 1984. Prinsip Pemasaran. Jakarta. Erlangga.

Sugiyono. 2005. Metode Penelitian Bisnis. Bandung. Alfabeta. . 2006. Metode Penelitian

Administrasi. Bandung. Alfabeta. 2008. Metode Penelitian Bisnis ( Pendekatan Kuantitatif, Kualitatif, dan $R \& D$ ). Bandung. Alfabeta. . 2009. Metode Penelitian

Kuantitatif dan Kualitatif. Bandung. Alfabeta. . 2010. Metode Penelitian

Administrasi. Bandung. Alfabeta. Swastha, Basu. 2002. Manajemen

Pemasaran. Edisi Kedua.

Cetakan Kedelapan. Jakarta.

Penerbit Liberty. dan Handoko. 1997.

Manajemen Pemasaran,

Analisa dan Perilaku

Konsumen. Yogyakarta. BPFE.

Swastha, Basu dan Handoko. 2004.

Manajemen Pemasaran

Modern. Jakarta. PT. Grasindo

Persada.

dan Irawan. 2001.
Manajemen

Modern. Yogyakarta. Liberty. 2003.

Manajemen Pemasaran

Modern. Yogyakarta. Liberty.

Tjiptono, Fandy. 2004. "Manajemen Jasa". Yogyakarta. Andy Offset.
. 2008. Strategi
Pemasaran. Edisi Ketiga.
Yogyakarta. Andy Offset.

Victor Supriadi. 2013. Kualitas

Produk, Merek, dan Harga

Pengaruhnya terhadap

Keputusan Pembelian

Konsumen pada Percetakan

Mitra Card di Manado. Jurnal EMBA Volume $1 \mathrm{No}$. $4 \mathrm{Hal}$. 831-840. Universitas Sam Ratulangi. Manado.

https://www.facebook.com/pages/M

OTTO-ORANG-ORANG-

PENTING-DI-DUNIA/

240686394273/John-Savique-

Capone/motto-

kesuksesan/diunduh tanggal 01

Juli 2014/09:25 PM. 